c. 2

\section{Fish \& Wildlife} Division

RESOURCE STATUS AND ASSESSMENT BRANCH

\section{Developing a Habitat-based Population Viability Model for Greater Sage-Grouse in Southeastern Alberta}

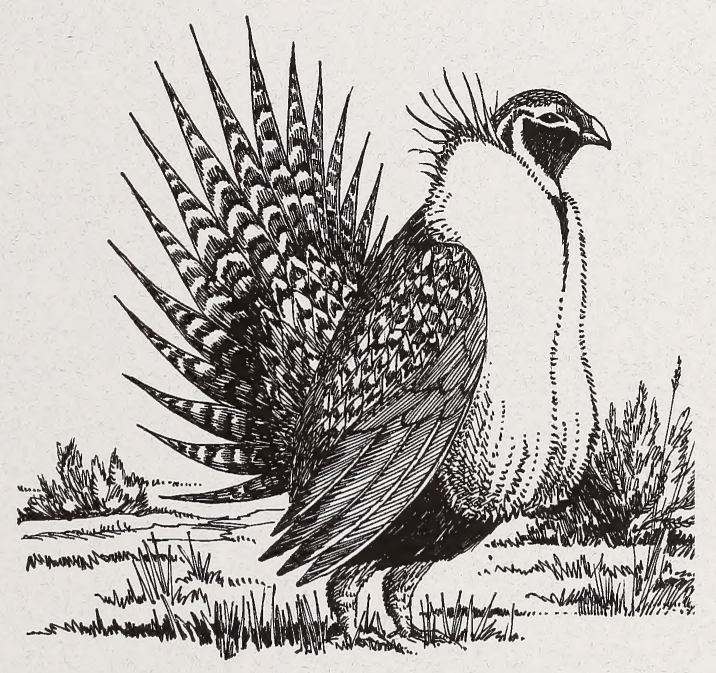

Alberta Species at Risk Report No. 56 
Digitized by the Internet Archive in 2016 


\title{
Developing a Habitat-based Population Viability Model for Greater Sage-Grouse in Southeastern Alberta
}

\section{Report}

\author{
Cameron L. Aldridge
}

Alberta Species at Risk Report No. 56

December 2001

Project Partners:
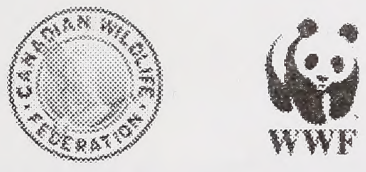

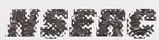

cons
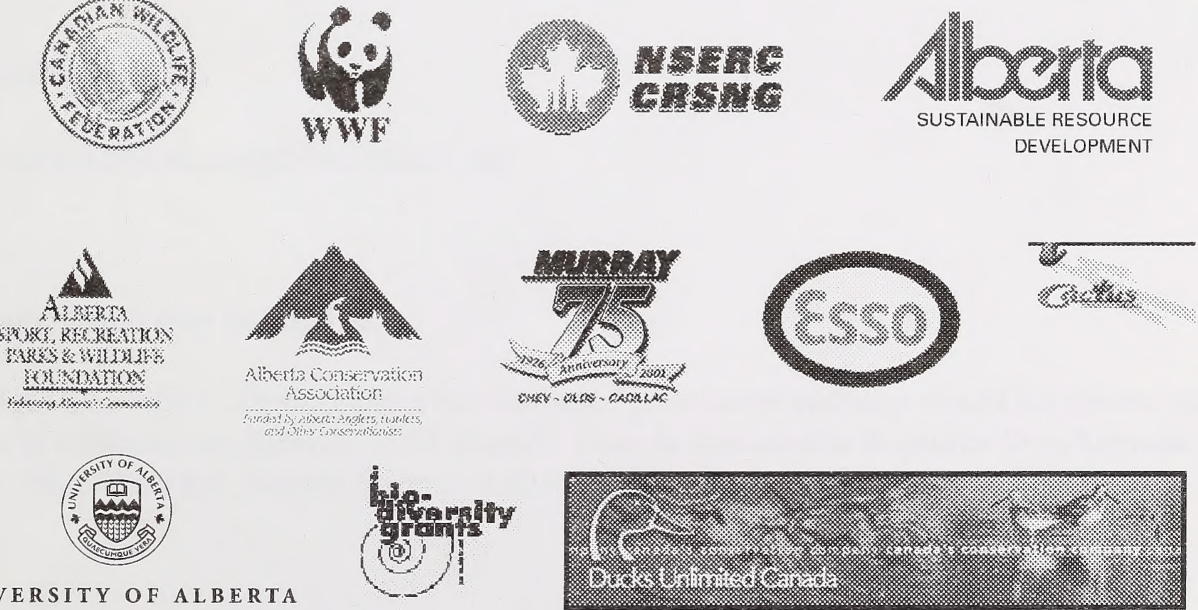
Publication No.: I/081

ISBN: 0-7785-2311-X (Printed Edition)

ISBN: 0-7785-2312-8 (On-line Edition)

ISSN: 1496-7219 (Printed Edition)

ISSN: 1496-7146 (On-line Edition)

Illustration: Brian Huffman

For copies of this report, contact:

Information Centre - Publications

Alberta Environment / Alberta Sustainable Resource Development

Main Floor, Great West Life Building

9920 - 108 Street

Edmonton, Alberta, Canada T5K 2M4

Telephone: (780) 422-2079

\section{OR}

Information Service

Alberta Environment / Alberta Sustainable Resource Development \#100, 3115 - 12 Street NE

Calgary, Alberta, Canada T2E 7J2

Telephone: (403) 297-3362

\section{OR}

Visit our web site at:

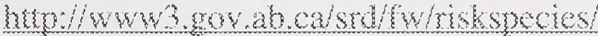

This publication may be cited as:

Aldridge, C.L. 2001. Developing a habitat-based population viability model for greater sagegrouse in southeastern Alberta. 2001 Report. Alberta Sustainable Resource Development, Fish and Wildlife Division, Alberta Species at Risk Report No. 56. Edmonton, AB. 12pp. 


\section{DISCLAIMER}

The views and opinions expressed are those of the author and do not necessarily represent the policies or positions of the Department or the Alberta Government. 

vii

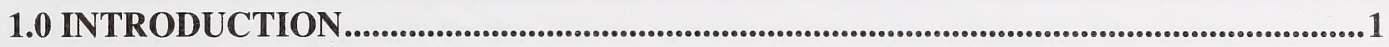

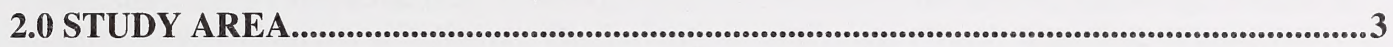

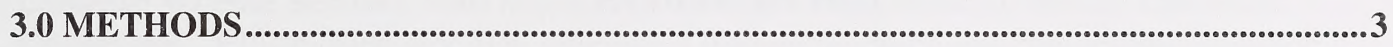

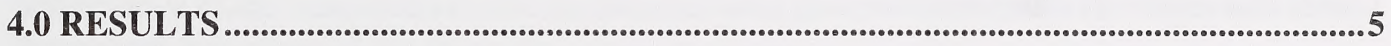

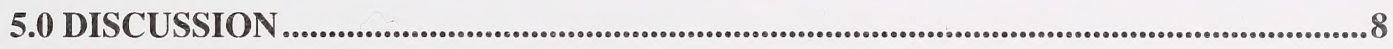

6.0 MANAGEMENT IMPLICATIONS AND FUTURE DIRECTIONS .............................9

7.0 LITERATURE CITED ..............................................................................................................11 


\section{LIST OF FIGURES}

Figure 1. Current and known historic distribution of sage-grouse ...........................................

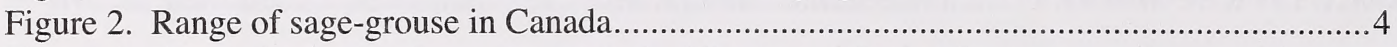

Figure 3. Population trends for sage-grouse in Alberta and Saskatchewan over the past 34 years.

\section{LIST OF TABLES}

Table 1. Body mass for birds captured in the 2001-breeding season in Alberta and the number of

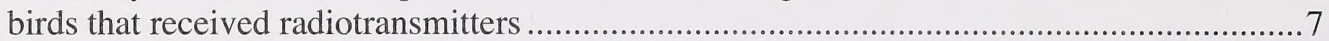




\section{ACKNOWLEDGEMENTS}

I thank D. Joanne Saher, Quinn E. Fletcher, and Craig W. Dockrill for their assistance and devotion to my research this summer. I also thank the many individuals that assisted with fieldwork and the logistics of my research. This research in was generously supported in 2001 financially and/or logistically by the Alberta Conservation Association, Alberta Sport, Recreation, Parks and Wildlife Foundation, Alberta Sustainable Resource Development, Cactus Communications (Medicine Hat, Alberta), Canadian Wildlife Foundation, Challenge Grants in Biodiversity (University of Alberta), Ducks Unlimited Canada (North American Waterfowl Management Plan), Endangered Species Recovery Fund (World Wildlife Fund Canada and the Canadian Wildlife Service), Esso Imperial Oil (Manyberries, Alberta), Murray Chevrolet Oldsmobile Cadillac (Medicine Hat, Alberta), a Natural Sciences and Engineering Research Council of Canada Scholarship to C.L. Aldridge, and the University of Alberta. I am appreciative of the many individuals and families who gave me permission to work on their land throughout the course of my research. 


\section{EXECUTIVE SUMMARY}

The greater sage-grouse population in Alberta has declined by $66-92 \%$ over the last 30 years. Previous research in Alberta suggests that the population has declined as a result of poor recruitment. Low levels of recruitment appear to be linked to poor chick survival as a result of limited mesic sites important for brood rearing habitat. Due to the inaccuracies of brood flushing counts and the limits of technology to produce transmitters small enough for chicks, it has been difficult to accurately assess and understand chick survival. Our previous population model developed from data gathered in 1998 and 1999 suggested that the population would continue to decrease in 2001, resulting in a decrease from 140 males counted on leks in 1999 to only 123 in 2001. One hundred and twenty-seven males were counted at seven active leks in 2001, which was similar to the number predicted by the model. However, in 2001, nest success (37\%) and chick survival (7.5-10\%) were both lower than values used to build the model and suggested that the population would likely decrease even further in 2002. Habitat use and selection at nest sites, brood-rearing locations and summer loafing sites were all assessed in order to obtain a better grasp of what variables might be related to the population decline. Samples of insects were collected at all brood-rearing locations to assess their importance in the diet of sage-grouse chicks. Habitat use of 16 radio-collared females will be assessed starting in January 2002 and will occur until the breeding season. All of these data will be used to develop population and habitat models that will be used to conduct population viability analyses for the sage-grouse population in Alberta. 


\subsection{INTRODUCTION}

Greater sage-grouse (Centrocercus urophasianus) historically occurred in British Columbia, Alberta, Saskatchewan and 16 U. S. States (Figure 1), but are currently extirpated from British Columbia and five states (Braun 1998). Throughout their range, sage-grouse have declined by an estimated 45-80\% since the 1950s (Braun 1998). The decline has been most severe at the northern fringe of the species' range, with the Alberta population experiencing a 66-92\% decline over the last 30 years (Aldridge and Brigham 2000). The reasons for this decline are uncertain, but previous research in Alberta suggests that poor habitat quality has reduced survival, particularly that of chicks (Aldridge and Brigham 2002). From this research, the population decline appears to be a result of high juvenile mortality leading to poor juvenile recruitment (Aldridge and Brigham 2001). Chick survival may be limited by available escape cover, due to limited grass and sagebrush (Artemisia cana) cover in southern Alberta (Aldridge and Brigham 2002). However, the lack of mesic sites and, thus, lush forbs (Aldridge and Brigham 2002) that are important in the diet of chicks (Johnson and Boyce 1990, Drut et al. 1994, Sveum et al. 1998) also may have reduced chick survival. This research indicated that nest success was within the normal range for sage-grouse; however, in years without above average precipitation, vegetation cover will not be a great, and nest success will likely decrease (Aldridge 2000a). Grass height was positively correlated with nest success for both artificial and natural sagegrouse nests (Aldridge and Brigham 2001, Watters et al. 2001), suggesting that habitat management could benefit productivity and chick survival of sage-grouse (Aldridge 2000a).

This was the first year of a multi-year project expanding on recent sage-grouse habitat research. The goal of this project is to relate habitat characteristics to measures of productivity and survival, and ultimately, the population size. Once fieldwork is complete, resource selection functions (RSFs) will be used to develop statistically rigorous models of habitat use and a habitat-based Population Viability Analysis (PVA; Manly et al. 1993, Boyce and McDonald 1999).

Specific objectives of the project are:

1. Implement experimental grazing manipulations to decrease grazing intensity on native prairie in southeastern Alberta. These manipulations will be designed to increase the residual grass cover and litter cover, and result in better moisture retention and forb growth, specifically in mesic habitats.

2. Continue to monitor the population through spring lek counts and trapping efforts.

3. Monitor reproductive effort, reproductive success, recruitment and survival, focusing on females and chicks.

4. Model the population using these parameters.

5. Assess habitat use at various life history stages using RSFs (for nesting and brood rearing periods and wintering areas).

6. Understand how sage-grouse respond to manipulations of habitat (selection of nest/brood sites within the manipulations; nest success and chick survival).

7. Assess chick survival (hatch to fledge) and overwinter survival (estimate recruitment).

8. Develop habitat use/probability maps to aid in habitat management for sage-grouse.

9. Develop a habitat-based population model for sage-grouse. 
SAGE GROUSE RANGE - 2000

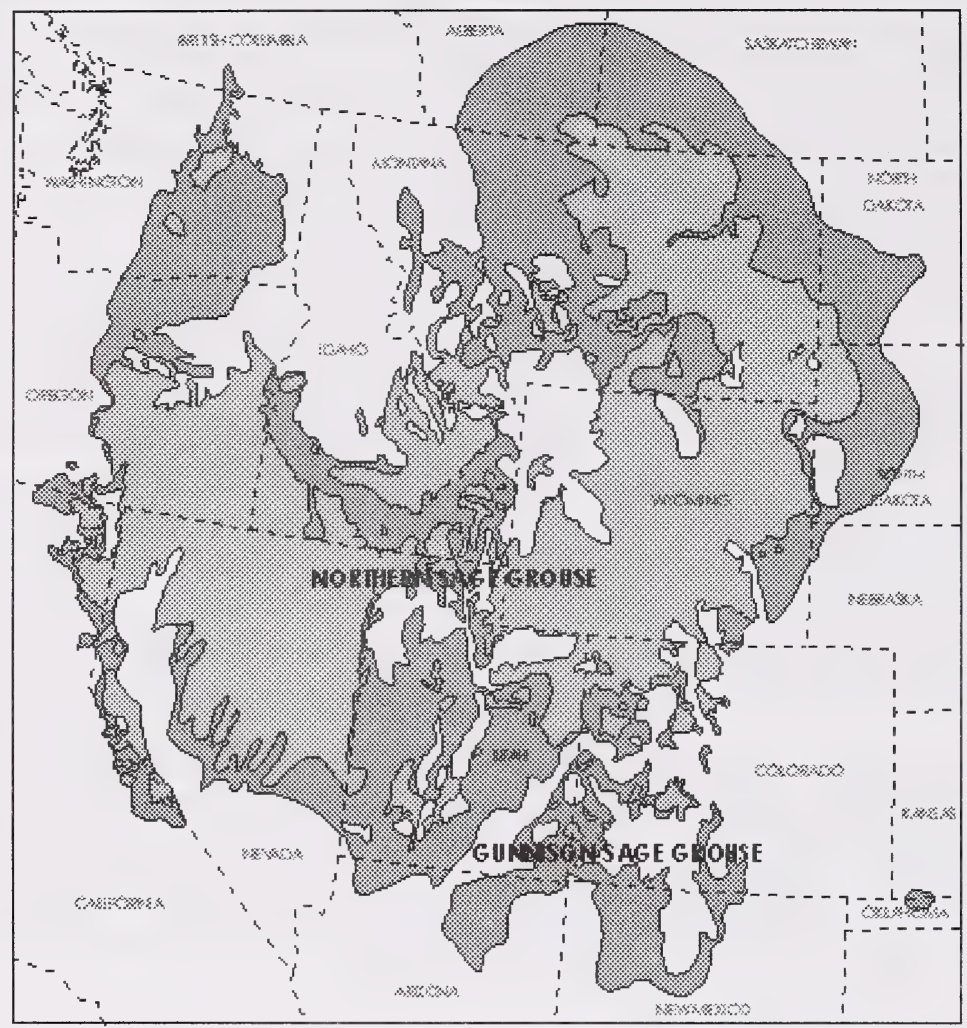

HSTONC RANGE

CURRENI RAMGE

Figure 1. Current and known historic distribution of northern or greater sage-grouse (Centrocercus urophasianus) and Gunnison sage-grouse (Centrocercus minimus) in North America. (Map Provided by Michael Schroeder, Washington Department of Fish and Wildlife). 


\subsection{STUDY AREA}

The study area is about $4000 \mathrm{~km}^{2}$ in size and is located in the southeast corner of Alberta, south of the Cypress Hills and east to the Saskatchewan border (Figure 2). This area represents the core range of sage-grouse in Canada and is composed of semi-arid mixed-grass prairie, with an abundance of silver sage (Aldridge 2000a).

\subsection{METHODS}

Lek counts were conducted from 26 March to 23 May 2001 at all previously known sage-grouse leks to obtain population estimates. Birds were trapped by spotlighting with a long-handled hoop net (Giesen et al. 1982) or in walk-in traps (Schroeder and Braun 1991). Necklace-style radio transmitters (Holohil Systems Inc., Carp, Ontario) were affixed to females only.

Once released, sage-grouse were tracked using a 5-element Yagi antenna and an R-1000 scanning telemetry receiver (Communications Specialists, Inc., Orange, CA). Birds were located using triangulation techniques until visually detected. Females were located and observed every other day during the nesting period (Musil et al. 1994, Schroeder 1997, Aldridge 2000a) in order to allow for nest fate to be determined. When approaching a nest, observers remained at least $30 \mathrm{~m}$ from the nest site (Aldridge 2000a). Nest locations were recorded in Universal Transverse Mercator coordinates (UTMs). Nest fate was determined and various measures of reproductive success were estimated (see Aldridge 2000a). Nest success was estimated as the percent of all nests that hatched at least one egg. Chick survival was estimated two ways; as the percent of hatched chicks that lived at least 50 days and as the percent of radiotagged chicks that survived to 50 days of age.

After nesting efforts ceased, nest site characteristics were measured (see Aldridge and Brigham 2002). At each nest site, the percent sagebrush canopy coverage, as well as the percent cover of grasses, forbs, non-palatable forbs (to sage-grouse), other shrubs and bare ground/dead materials were estimated within a $1 \mathrm{~m}^{2}$ quadrat using a method similar to Daubenmire's (1959). The amount of residual grass cover and litter build-up was also measured. The mean maximum height of the aforementioned variables was also calculated for each plot. To determine whether habitat characteristics near nest sites are important, 8 additional dependent non-random $1 \mathrm{~m}^{2}$ plots were placed at $7.5 \mathrm{~m}$ and $15 \mathrm{~m}$ from the nest in each of the four ordinal directions and the same measurements were performed (Aldridge 2000a). A modification of Canfield's (1941) line intercept method was used to estimate the live sagebrush canopy coverage along four $15 \mathrm{~m}$ transects radiating from the nest site in the four ordinal directions (Aldridge 2000a). A similar set of habitat characteristics were also taken at a set of plots at a randomly related site, $100 \mathrm{~m}$ to $500 \mathrm{~m}$ in a random direction from the nest site (dependent random plots). The dependent nonrandom plots represent non-nest site characteristics within the same 'stand', and the dependent random plots represent non-nest site characteristics from different 'stands'. Insect pitfall traps were placed at all brood locations and at paired random locations. Nine traps were placed at each location for three days, according to a set pattern: one trap was placed at the use site, and one trap was placed at each of $5 \mathrm{~m}$ and $10 \mathrm{~m}$ away, for each of the 4 ordinal directions. Insect pitfall traps were made from $300 \mathrm{ml}$ plastic cups containing $200 \mathrm{ml}$ of a mild soap solution. 


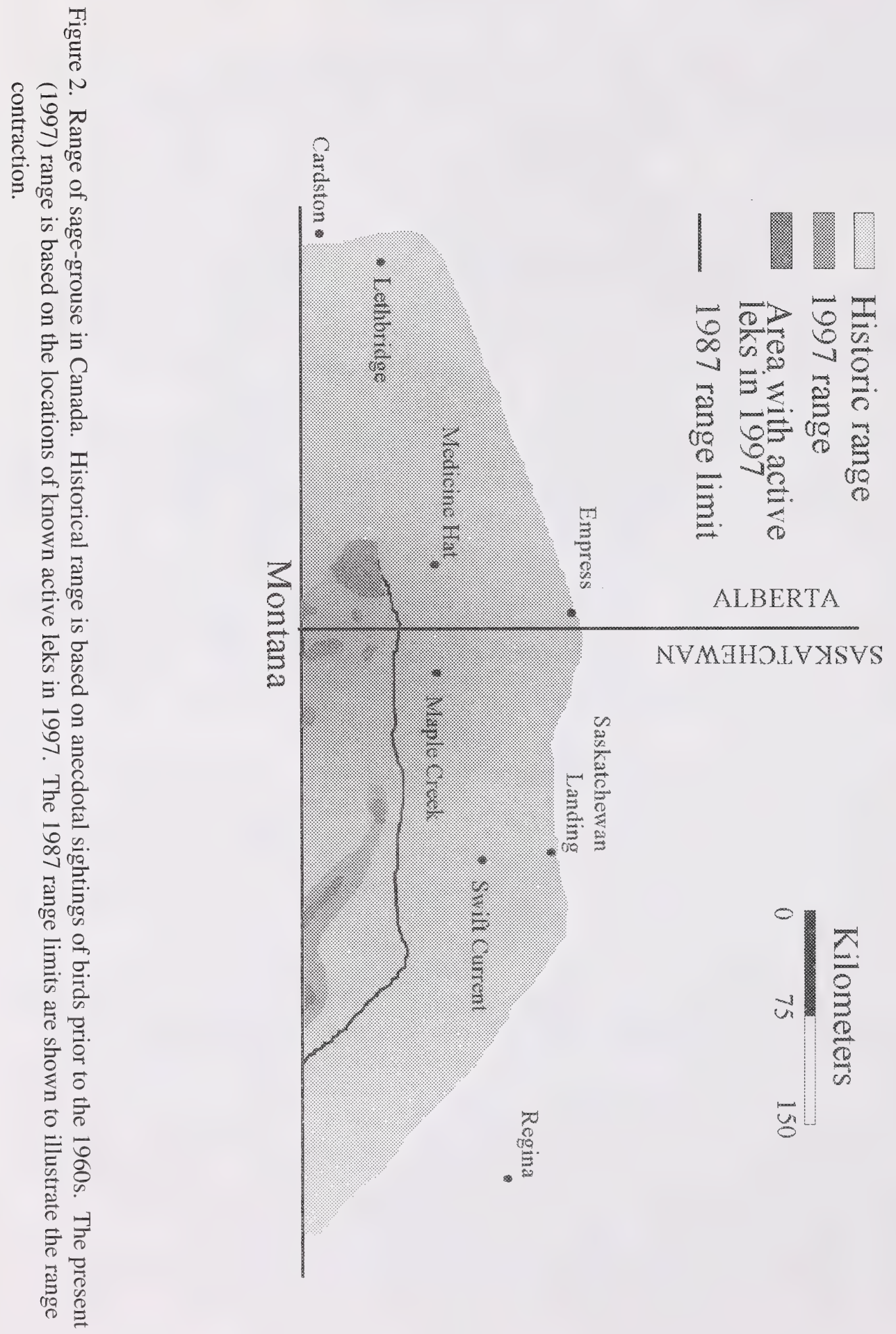


Radio-collared birds were followed throughout the spring and summer to obtain information on habitat use. Each week, females with or without broods were tracked (Musil et al. 1994, Schroeder 1997, Aldridge 2000a), and the same habitat measurements described for nest sites were performed at use site and random locations. Brooding females were not intentionally flushed until chicks were at least three weeks of age, and then brood flush counts were performed to estimate chick survival when females were located. Two chicks from each brood were captured and fitted with radio-transmitters.

Chick transmitters were attached along the dorsal midline with two sutures (5-0 non-absorbable sterile surgical thread, Aldridge 2000b). A small drop of Skin-Bond surgical adhesive (Smith and Nephew Inc., Largo, FL) was applied between the transmitter and the chick's back before tying the sutures to ensure that the transmitter and sutures did not catch on any vegetation as the chick grew. Chicks were triangulated every second day to determine if they were still with the hen. If signals were separated, the location of the chick's radio-signal was determined to confirm whether the chick was still alive. Broods less than three weeks of age were observed from close range with binoculars. The goal was to recapture these radio-tagged chicks at 12 weeks of age, and replace their transmitters with a full size necklace-style adult transmitter.

\subsection{RESULTS}

\subsection{Population Trends}

In 2001, lek counts over the strutting period resulted in a maximum number of 127 males being counted on seven active leks (Figure 3). Despite the drastic decrease in population numbers since the mid 1980s, counts have only slightly decreased over the last seven years (Figure 3). All historical lek locations were checked for signs of use, and seven of the eight leks that were actively used in 2000 were used in 2001. One lek that had a single male in 2000 was inactive.

\subsection{Adult Captures}

Radio signals from all five females that were tracked in August 2000 were located prior to breeding in 2001. One of these females was killed in late March, before the breeding season. All of these females were originally captured in 1999, and thus their radio signals were slowly decreasing in strength. One transmitter quit before information on the breeding season could be gathered in 2001. One female was captured prior to the breeding season and a new transmitter was attached; however, this bird was killed by a predator prior to nesting. Thirty-six females (29 adults and 7 yearlings; one was a recaptured adult) and 16 males (14 adults and 2 yearlings) were captured during the 2001 breeding season (Table 1). Masses of males and females (adults and yearlings) were similar to masses in previous years (Table 1). All females received a radio transmitter. Thus, a total of 39 females had radio collars at the beginning of the 2001 breeding season. Seventeen percent of the birds captured in 2001 were yearlings. 

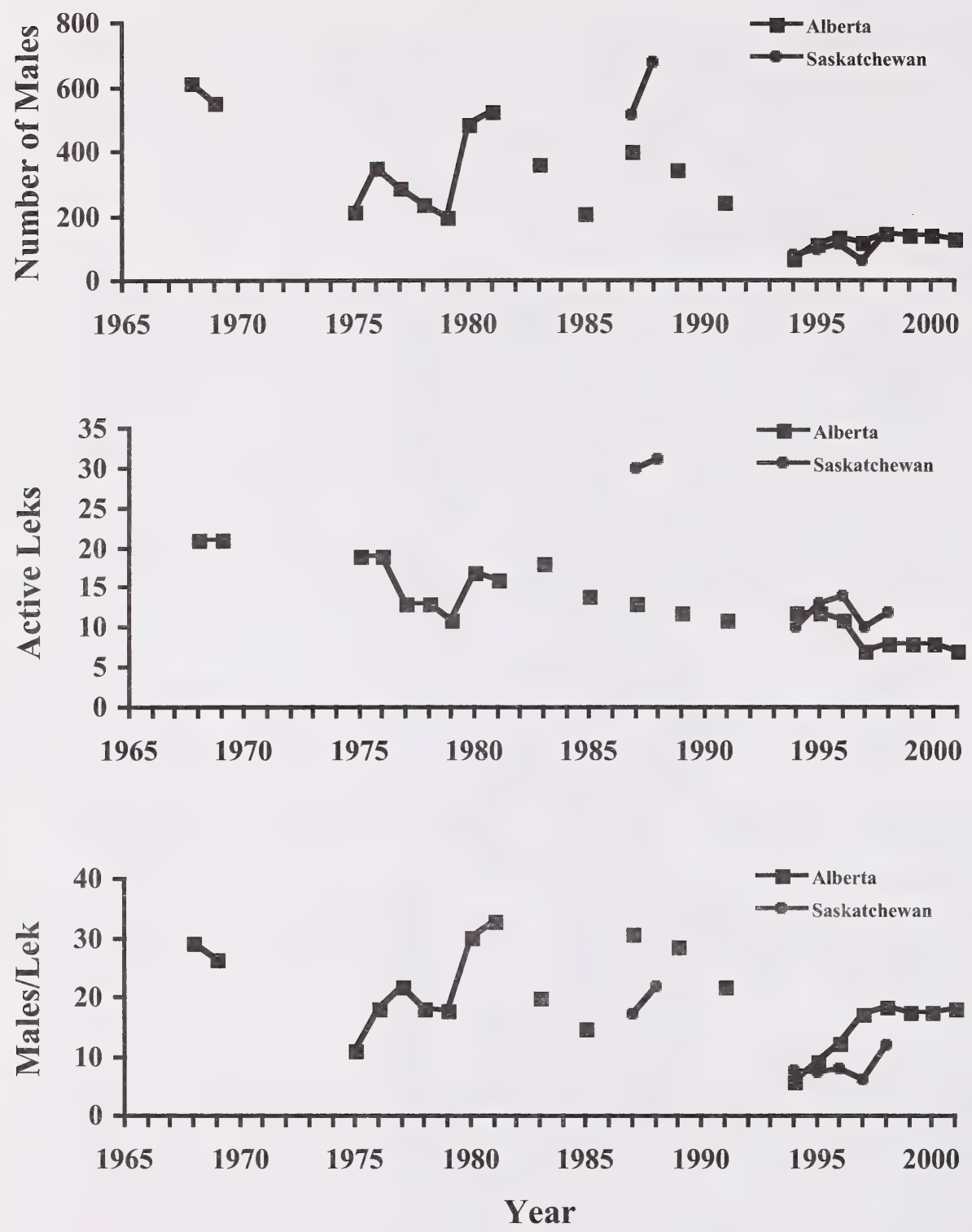

Figure 3. Population trends for sage-grouse in Alberta and Saskatchewan over the past 34 years, shown as the number of males, number of males per lek, and number of active leks. Years when sampling efforts consisted of less than eight surveyed leks were not included. 
Table 1. Body mass for birds captured in the 2001-breeding season in Alberta and the number of birds that received radio transmitters. One adult female originally captured in 1999 was recaptured and included in the mass calculations. Standard errors are shown in brackets.

\begin{tabular}{ccccc} 
& \multicolumn{2}{c}{ Adults } & \multicolumn{2}{c}{ Yearlings } \\
\hline & Males & Female & Male & Female \\
\hline Captures & 14 & 29 & 2 & 7 \\
Mass & 3101 & 1583 & 2563 & 1526 \\
& $(50.8)$ & $(16.7)$ & $(57.0)$ & $(38.5)$ \\
Radios & 0 & 29 & 0 & 7 \\
\hline
\end{tabular}

\subsection{Reproductive Activities}

One radio from a bird captured in 1999 ceased transmitting early in the breeding season in 2001. Six females disappeared prior to the breeding season; the reasons for their disappearance are unknown but could be due to predation or equipment failure.

Five females were killed early in the breeding season and one female moved onto land to which access was not granted. This bird may have nested there, as its signal was detected at the site from fixed-wing aircraft throughout the breading season and summer.

Reproductive data were gathered for 26 different radio-collared females, two of which did not appear to initiate nesting activities. Twenty-five nests were located for 24 different radiocollared individuals (one female renested), and 2 nests were found from unmarked birds, for a total of 27 nests. Nest success was 37\% (10/27 nests). Shortly after their first nesting attempt failed 6 females disappeared. Of the remaining females, only $12.5 \%$ ( 1 of 8 ) renested.; 3 of the 12 unsuccessful females were killed shortly after initial nesting attempts.

Mean clutch size over all nests was 7.5 eggs per nest $( \pm 0.49, \mathrm{n}=21$; clutch size could not be estimated for 6 failed nesting attempts) and averaged 8.6 eggs $( \pm 0.18, \mathrm{n}=10)$ for successful nests. Egg viability was $93 \%$, with 80 of 86 eggs laid in successful nests hatching.

One radio failed while a female was on the nest, but her nest was successful. She could not be recaptured, but was tracked after radio-collars were affixed to two of her chicks. Both chicks subsequently died. All radio-collared females were tracked during the remainder of the summer. Sixteen radio-collared females were still alive at the end of August 2001.

\subsection{Chick Transmitters}

Fifty-eight chicks were captured from eight different broods. Radio-transmitters were affixed to 14 chicks: 2 chicks from each of 6 broods and 1 chick from each of 2 broods. All chicks were captured within 3 days of hatching, and averaged $31 \pm 1.9 \mathrm{~g}$ at the time of capture. Transmitters weighed $1.6 \mathrm{~g}$, and represented a $5.1 \%$ increase in mass of the newly hatched chicks. 
One transmitter failed three days after deployment. That chick was recaptured and the radiotransmitter was removed. At 50 days of age, brood flush counts indicated that only 3 females still had broods, with a total of only 6 chicks being observed. Chick survival from flush counts was estimated to be $7.5 \%$ ( 6 of 80 chicks). Chick survival estimated from the 13 remaining radio-tagged chicks was $10 \%$ ( 1 of 10 chicks); 3 of the chicks could not be relocated, 9 were confirmed dead, and 1 survived to more than 50 days of age.

Kill sites were not located for any dead radio-tagged chicks. However, three chick transmitters were found in coyote scat, one was found in fox or badger scat, and four transmitters were located with bite marks in them. The last chick fell into an unused badger burrow and perished.

\subsection{Habitat Measurements}

Vegetation data were gathered at 157 sage-grouse use sites and 157 random locations. These included 27 nest sites, 43 brood rearing locations from 7 different broods, and 87 locations from broodless females. Data on insect availability were collected at each brood use site and each corresponding random location. The insect/food selection and availability data will be analysed in the future with habitat data, and incorporated into resource selection models.

\subsection{DISCUSSION}

The population model developed by Aldridge (2000a) predicted that the sage-grouse population in Alberta should continue to decline in 2000. The model suggested that the population should decrease from a spring estimate of 420-622 individuals in 1999, to between 397 and 598 individuals in 2000, and to 368 to 545 individuals in 2001 (Aldridge 2000a). The number of males attending leks was predicted to decline from 140 males in 1999 to 132 in 2000, and to 123 in 2001. One hundred and forty males were counted on leks in 2000, which was slightly higher than predicted, but this number dropped to 127 males on 7 active leks in 2001 (Figure 3). The 2001 spring sage-grouse population for Alberta was estimated at 381-465, down from the estimate in 2000. The population estimate for 2001 was similar to the predicted estimate (368545) from the 1999 population model (Aldridge 2000a).

While the model is useful for predicting general population trends, caution needs to be used when predicting the actual population size, especially when all of the assumptions associated with lek counts are considered (Braun et al. 1977, Jenni and Hartzler 1978, Aldridge 2000a). Each parameter in the model is highly variable, and a better understanding of the variability inherent in each parameter is starting to be achieved.

The model assumes that female overwinter survival is $100 \%$, as data on overwinter survival of females are not available. Information on habitat use during the winter is needed to refine the model. One of the objectives of this research was to track radio-collared juvenile sage-grouse over the winter to better understand winter habitat selection and requirements and to obtain estimates of adult and juvenile overwinter survival and improve the model. However, poor 
nesting success and poor chick survival precluded juveniles from being followed during winter 2001-2002. Radio-collared females that were alive in August 2001 will be tracked for 3 months starting in January 2002.

Nest success in 2001 (37\%) was lower that that over 1998-1999 (46\%, Aldridge and Brigham 2001). However, it was higher than nest success in 2000 (20\%), although sample sizes were small in 2000 (Aldridge 2000b). This year was the first year that some females did not attempt to nest. The extreme drought may have led to reduced nesting effort and renesting attempts, resulting in poor recruitment. Only 17\% of 52 birds captured in 2001 were yearlings. This number should be around 50\% for a stable population (Aldridge 2000a). From 1998 to 2000, $25 \%$ of 133 birds captured during the breeding season were yearlings, suggesting that recruitment into the 2001 spring population was lower than in the previous 3 years.

Mean clutch size for sage-grouse typically ranges from 6-9 eggs (Patterson 1952, Connelly et al. 1993, Anonymous 1997, Schroeder 1997, Schroeder et al. 1999). In the past, clutch size in Alberta has averaged between 6.9 eggs per nest (Aldridge 2000b) and 7.75 eggs per nest (Aldridge and Brigham 2001). Despite the dry winter and spring, which may limit food resources that are important to pre-laying hens (Barnett and Crawford 1994), clutch size in 2001 averaged 7.5 eggs per nest. However, the drought likely resulted in increased nest failures and decreased the ability of females to initiate a renesting attempt - only one female renested.

Estimates of chick survival from the radio-tagged chicks (10\%) yielded similar results to those from the brood flush counts $(7.5 \%)$. Chick survival was the lowest it has been in the last four years, probably as a result of drought conditions. It is encouraging to see that flush counts may be an accurate measure of chick survival, but increased sample sizes are required to fully understand the causes of chick mortalities. With these low reproductive rates, the 2002 spring population may decline even further, and fall below values predicted from the population model.

\subsection{MANAGEMENT IMPLICATIONS AND FUTURE DIRECTIONS}

Objectives for the project outlined earlier have all been addressed. Collection of information on winter habitat use has not yet begun, but will start in January 2002. In the future, data will also be collected on winter habitat use and survival of juvenile birds.

The Public Lands Division of Alberta Sustainable Resource Development is working with local landowners and lessees to implement experimental grazing trials (see objectives 1 and 6 in the Introduction). The intent of these trials is to work with ranchers to experimentally decrease grazing intensity in mesic habitats that are important for brood rearing. The goal of these trials will be to increase the abundance and quality of wet forb rich habitats as well as increase the amount of residual cover important for concealment of nests and escape cover for adults and broods. These changes may require several years to show results. Once implemented, experimental sites should be monitored to document changes in the vegetation community and structure. Production and survival of sage-grouse also needs to be monitored to understand how grouse respond to changes in grazing management and to determine if the management 
applications are having the desired effects. If not, the treatments need to be assessed and modified as necessary, following the principles of adaptive management.

Once fieldwork is completed, the information will be used to develop Resource Selection Function (RSF) models for sage-grouse in Alberta. These models will be used to develop a habitat-based Population Viability Analysis (PVA) for the Alberta population. Development of the PVA will address objectives 5, 8 and 9 of the Introduction. 


\subsection{LITERATURE CITED}

Aldridge, C. L. 2000a. Reproduction and habitat use by sage grouse (Centrocercus urophasianus) in a northern fringe population. M.Sc. thesis, University of Regina, Regina, SK. 109 pp.

Aldridge, C. L. 2000b. Assessing chick survival of sage grouse in Canada. Alberta Sustainable Resource Development, Fish and Wildlife Service, Alberta Species at Risk Report No. 19. Edmonton, Alberta. 25 pp.

Aldridge, C. L., and R. M. Brigham. 2000. Status and distribution of sage grouse in Canada. Submitted to Canadian Field-Naturalist. 44 pp.

Aldridge C. L., and R. M. Brigham. 2001. Nesting and reproductive activities of greater sage grouse in a declining northern fringe population. Condor 103:537-543.

Aldridge, C. L., and R. M. Brigham. 2002. Sage-grouse nesting and brood habitat use in southern Canada. Journal of Wildlife Management 66(2):433-444.

Anonymous. 1997. Gunnison sage grouse conservation plan. Colorado Division of Wildlife. $108 \mathrm{pp}$.

Barnett, J. K., and J. A. Crawford. 1994. Pre-laying nutrition of sage grouse hens in Oregon. Journal of Range Management 47:114-118.

Braun, C. E., T. Britt, and R. O. Wallestad. 1977. Guidelines for maintenance of sage grouse habitats. Wildlife Society Bulletin 5:99-106.

Braun, C. E. 1998. Sage grouse declines in western North America: what are the problems? Proceedings of the Western Association of Fish and Wildlife Agencies and the Western Division, American Fisheries Society 78:139-156.

Boyce, M. S., and L. L. McDonald. 1999. Relating populations to habitats using resource selection functions. Tree 14:268-272.

Canfield, R. H. 1941. Application of the line interception method in sampling range vegetation. Journal of Forestry 39:388-394.

Connelly, J. W., R. A. Fischer, A. D. Apa, K. P. Reese, and W. L. Wakkinen. 1993. Renesting by sage grouse in southeastern Idaho. Condor 95:1041-1043.

Daubenmire, R. F. 1959. A canopy coverage method of vegetational analysis. Northwest Science 33:43-46.

Drut, M. S., J. A. Crawford, and M. A. Gregg. 1994. Brood habitat use by sage grouse in Oregon. Great Basin Naturalist 54:170-176. 
Giesen, K. M., T. J. Schoenberg, and C. E. Braun. 1982. Methods for trapping sage grouse in Colorado. Wildlife Society Bulletin 10:223-231.

Jenni, D. A., and J. E. Hartzler. 1978. Attendance at a sage grouse lek: implications for spring census. Journal of Wildlife Management 43:46-52.

Johnson, G. D., and M. S. Boyce. 1990. Feeding trials with insects in the diet of sage grouse chicks. Journal of Wildlife Management 54:89-91.

Manly, B. F. J., L. L. McDonald, and D. L. Thomas. 1993. Resource selection by animals: statistical design and analysis for field studies. Chapman and Hall, London, UK. 177 pp.

Musil, D. D., K. P. Reese, and J. W. Connelly. 1994. Nesting and summer habitat use by translocated sage grouse (Centrocercus Urophasianus) in central Idaho. Great Basin Naturalist 54:228-233.

Patterson, R. L. 1952. The sage grouse in Wyoming. Sage Books, Denver. 341 pp.

Schroeder, M. A. 1997. Unusually high reproductive effort by sage grouse in a fragmented habitat in North-Central Washington. Condor 99:933-941.

Schroeder, M. A., and C. E. Braun. 1991. Walk-in traps for capturing greater prairie-chickens on leks. Journal of Field Ornithology 62:378-385.

Schroeder, M. A., J. R. Young, and C. E. Braun. 1999. Sage grouse (Centrocercus urophasianus). In The Birds of North America, No. 425 (A Pool and F. Gill, eds.). The Birds of North America, Inc., Philadelphia, PA. 28 pp.

Sveum, C. M., J. A. Crawford, and W. D. Edge. 1998. Use and selection of brood-rearing habitat by sage grouse in south-central Washington. Great Basin Naturalist 58:344-351.

Watters, M. E., T. L. McLash, C. L. Aldridge, and R. M. Brigham. 2001. The effect of vegetation structure on the fate of artificial greater sage grouse nests. Ecoscience 9(3): In Press. 
(as of December 2002)

No. 1 Alberta species at risk program and projects 2000-2001, by Alberta Sustainable Resource Development, Fish and Wildlife Division. (2001)

No. 2 Survey of the peregrine falcon (Falco peregrinus anatum) in Alberta, by R. Corrigan. (2001)

No. 3 Distribution and relative abundance of the shortjaw cisco (Coregonus zenithicus) in Alberta, by M.

Steinhilber and L. Rhude. (2001)

No. 4 Survey of the bats of central and northwestern Alberta, by M.J. Vonhof and D. Hobson. (2001)

No. 52000 survey of the Trumpeter Swan (Cygnus buccinator) in Alberta, by M.L. James and A. James. (2001)

No. 6 2000/2001 Brassy Minnow inventory at Musreau Lake and outlet, by T. Ripley. (2001)

No. 7 Colonial nesting waterbird survey in the Northwest Boreal Region - 2000, by M. Hanneman and M. Heckbert. (2001)

No. 8 Burrowing owl trend block survey and monitoring - Brooks and Hanna areas, by D. Scobie and R. Russell. (2000)

No. 9 Survey of the Lake Sturgeon (Acipenser fulvescens) fishery on the South Saskatchewan River, Alberta (June-September, 2000), by L.A. Winkel. (2000)

No. 10 An evaluation of grizzly bear-human conflict in the Northwest Boreal Region of Alberta (1991-2000) and potential mitigation, by T. Augustyn. (2001)

No. 11 Harlequin duck monitoring in the Northern East Slopes of Alberta: 1998-2000 preliminary results, by J. Kneteman and A. Hubbs. (2000)

No. 12 Distribution of selected small mammals in Alberta, by L. Engley and M. Norton. (2001)

No. 13 Northern leopard frog reintroduction. Raven River - Year 2 (2000), by K. Kendell. (2001)

No. 14 Cumulative effects of watershed disturbances on fish communities in the Kakwa and Simonette watersheds. The Northern Watershed Project. Study 3 Progress report, by T. Thera and A. Wildeman. (2001)

No. 15 Harlequin duck research in Kananaskis Country in 2000, by C.M. Smith. (2001)

No. 16 Proposed monitoring plan for harlequin ducks in the Bow Region of Alberta, by C.M. Smith. (2001)

No. 17 Distribution and relative abundance of small mammals of the western plains of Alberta as determined from great horned owl pellets, by D. Schowalter. (2001)

No. 18 Western blue flag (Iris missouriensis) in Alberta: a census of naturally occurring populations for 2000, by R. Ernst. (2000)

No. 19 Assessing chick survival of sage grouse in Canada, by C.L. Aldridge. (2000)

No. 20 Harlequin duck surveys of the Oldman River Basin in 2000, by D. Paton. (2000)

No. 21 Proposed protocols for inventories of rare plants of the Grassland Natural Region, by C. Wallis. (2001) 
No. 22 Utilization of airphoto interpretation to locate prairie rattlesnake (Crotalus viridis viridis) hibernacula in the South Saskatchewan River valley, by J. Nicholson and S. Rose. (2001)

No. 23 2000/2001 Progress report on caribou research in west central Alberta, by T. Szkorupa. (2001)

No. 24 Census of swift fox (Vulpes velox) in Canada and Northern Montana: 2000-2001, by A. Moehrenschlager and C. Moehrenschlager. (2001)

No. 25 Population estimate and habitat associations of the long-billed curlew in Alberta, by E.J. Saunders. (2001)

No. 26 Aerial reconnaissance for piping plover habitat in east-central Alberta, May 2001, by D.R.C. Prescott. (2001)

No. 27 The 2001 international piping plover census in Alberta, by D.R.C. Prescott. (2001)

No. 28 Prairie rattlesnake (Crotalus viridis viridis) monitoring in Alberta - preliminary investigations (2000), by S.L. Rose. (2001)

No. 29 A survey of short-horned lizard (Phrynosoma hernandesi hernandesi) populations in Alberta, by J. James.

No. 30 Red-sided garter snake (Thamnophis sirtalis parietalis) education and relocation project - final report, by L. Takats. (2002)

No. 31 Alberta furbearer harvest data analysis, by K.G. Poole and G. Mowat. (2001)

No. 32 Measuring wolverine distribution and abundance in Alberta, by G. Mowat. (2001)

No. 33 Woodland caribou (Rangifer tarandus caribou) habitat classification in northeastern Alberta using remote sensing, by G.A. Sanchez-Azofeifa and R. Bechtel. (2001)

No. 34 Peregrine falcon surveys and monitoring in the Parkland Region of Alberta, 2001, by R. Corrigan. (2002)

No. 35 Protocol for monitoring long-toed salamander (Ambystoma macrodactylum) populations in Alberta, by T. Pretzlaw, M. Huynh, L. Takats and L. Wilkinson. (2002)

No. 36 Long-toed salamander (Ambystoma macrodactylum) monitoring study in Alberta: summary report 19982001, by M. Huynh, L. Takats and L. Wilkinson. (2002)

No. 37 Mountain plover habitat and population surveys in Alberta, 2001, by C. Wershler and C. Wallis. (2002)

No. 38 A census and recommendations for management for western blue flag (Iris missouriensis) in Alberta, by R. Ernst. (2002)

No. 39 Columbian mountain amphibian surveys, 2001, by D. Paton. (2002)

No. 40 Management and recovery strategies for the Lethbridge population of the prairie rattlesnake, by R. Ernst. (2002)

No. 41 Western (Aechmophorus occidentalis) and eared (Podiceps nigricollis) grebes of central Alberta: inventory, survey techniques and management concerns, by S. Hanus, H. Wollis and L. Wilkinson. (2002)

No. 42 Northern leopard frog reintroduction - year 3 (2001), by K. Kendell. (2002)

No. 43 Survey protocol for the northern leopard frog, by K. Kendell. (2002)

No. 44 Alberta inventory for the northern leopard frog (2000-2001), by K. Kendell. (2002)

No. 45 Fish species at risk in the Milk and St. Mary drainages, by RL\&L Environmental Services Ltd. (2002) 
No. 46 Survey of the loggerhead shrike in the southern aspen parkland region, 2000-2001, by H. Kiliaan and D.R.C. Prescott. (2002)

No. 47 Survey of native grassland butterflies in the Peace parkland region of northwestern Alberta - 2001, by M. Hervieux. (2002)

No. 48 Caribou range recovery in Alberta: 2001/02 pilot year, by T. Szkorupa. (2002)

No. 49 Peace parkland native grassland stewardship program 2001/02, by A. Baker. (2002)

No. 50 Carnivores and corridors in the Crowsnest Pass, by C. Chetkiewicz. (2002)

No. 512001 Burrowing owl trend block survey and monitoring, Brooks and Hanna areas, by D. Scobie. (2002)

No. 52 An evaluation of the ferruginous hawk population in Alberta based on recent trend data, by D.P. Stepnisky, G.L. Erickson, J. Iwaasa and B. Taylor. (2002)

No. 53 Alberta amphibian call surveys. A pilot year. Final report, by L. Takats and C. Priestley. (2002)

No. 54 Utilization of a roadside survey technique to survey burrowing owl (Athene cunicularia hypugaea) in southeastern Alberta, by J. Nicholson and C. Skiftun. (2002)

No. 55 Alberta species at risk program and projects 2001-2002, by Alberta Sustainable Resource Development, Fish and Wildlife Division. (2002)

No. 56 Developing a habitat-based population viability model for greater sage-grouse in southeastern Alberta, by C.L. Aldridge. (2001)

No. 57 Peregrine falcon surveys and monitoring in the Northeast Boreal Region of Alberta, 2001, by R. Corrigan. (2002)

No. 582002 burrowing owl trend block survey and monitoring, Brooks area, by R.F. Russell. (2002)

No. 59 Rare plant inventory of the eastern edge of the lower foothills natural subregion, west-central Alberta, by J. Doubt. (2002)

No. 60 Western (Aechmophorus occidentalis) and eared (Podiceps nigricollis) grebes of central Alberta: 2002 field summary, by S. Hanus, H. Wollis and L. Wilkinson. (2002)

No. 61 Inventory of western spiderwort (Tradescantia occidentalis) in Alberta: 2002, by S. Peters. (2003) 

National Library of Canada
Bibliothèque nationalu

Bibliothèque nationale du Canada

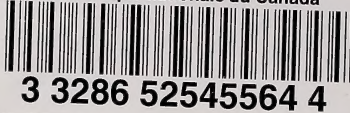

